\title{
1. The rule of law as a social imaginary
}

The rule of law does not promise results so much as it promises an approach, a process, a practice of reason-giving, a set of argumentative conventions. (Torke 2001, p. 1450)

Studying the law we become part of it. The consequence is that our deepest cultural commitment - the commitment to the rule of law - remains one of the least explored elements of our common life. (Kahn 1999, p. 2)

Such a high degree of consensus on the virtues of the rule of law is possible because of relative vagueness as to its meaning. (Chesterman 2008a, p. 3)

As I hope I have demonstrated in the Introduction, the idea of the rule of law is often appealed to in discussions of, and deliberations about, politics. Now I want to suggest that one useful way of understanding the contemporary resonance of the rule of law is to regard it is a 'social imaginary'. Charles Taylor's idea of the 'social imaginary' stems from his focus on the "way ordinary people "imagine" their social surroundings' carried in 'images, stories and legends'; he focuses on ideas that are shared by 'large groups of people, if not the whole of society'; and on those ideas that represent a 'common understanding that makes possible common practices and a widely shared sense of legitimacy' (Taylor 2004, p. 23); a social imaginary is a particular form of common sense. Taylor sees a social imaginary as complex while

incorporat[ing] a sense of the normal expectations we have of each other, the kind of common understanding that enables us to carry out the collective practices that make up our social life ... [and] some sense of how we all fit together in carrying out this common practice. Such understanding is both factual and normative; that is, we have a sense of how things usually go, but this is interwoven with an idea of how they ought to go, of what missteps would invalidate the process. (Taylor 2004, p. 24)

Moreover, this includes a clear recognition of ideal cases from which judgements can then be made as regards the fit between the imaginary and the practice. Beyond this set of ideals 'stands some notion of a moral or metaphysical order, in the context of which the norms and ideals make sense'. Thus, the social imaginary is a 'wider grasp of our whole predicament; 
how we stand to each other, how we got to where we are, how we relate to other groups and so on'. We need to understand our practice for it to make sense to us and for us to act, but this wider set of ideas has no necessary limits for Taylor. Thus, it 'can never be adequately expressed in the form of explicit doctrines because of its unlimited and indefinite nature' (Taylor 2004, p. 25). It is fluid and under-defined in a formal sense but nevertheless shared as a story of how we are, alongside a clear idea about 'what makes these norms realizable' (Taylor 2007, p. 175). Already it seems to me that this has some applicability to the idea of the rule of law, whatever debates there are about its meaning in jurisprudence and elsewhere.

The practices and understandings encompassed by such a social imaginary do not relate to each other in a unidirectional manner; 'If understanding makes the practice possible, it is also true that it is the practice that largely carries the understanding.' That is to say: 'At any given time we can speak of the "repertory" of collective actions at the disposal of a given group of society. These are the common actions that they know how to undertake' (Taylor 2004, p. 25). This common understanding does not require theorization in the first instance; it is what we know we need to do to be part of society. Therefore, the

understanding of what we're doing right now (without which we couldn't be doing this action) makes the sense it does because of our grasp on the wider predicament: how we continuously stand or have stood in relation to others and to power. This in turn, opens out wider perspectives on where we stand in space and time: our relations to other nations and peoples ... and also where we stand in our history, in the narrative of our becoming. (Taylor 2004, p. 27)

New theories may penetrate this generalized notion of the possible, and eventually, as it is more widely recognized (or accepted) and adopted, so the social imaginary's new element 'begins to define the contours of their world and can eventually come to count as the taken-for-granted shape of things, too obvious to mention' (Taylor 2004, p. 29). However, Taylor also warns that the recognition of a new social imaginary should not be taken to indicate that it has completely replaced forgoing understandings (rather it will continue to interact with these previous understandings), and although it may also seem to have become self-evident, the job of analysis and engagement is to unpick this obviousness to reveal the history and construction of the social imaginary as currently manifest (Taylor 2007, pp. 168, 169). Its development must be therefore regarded as dynamic and social.

For Taylor, anticipating Margaret Archer's approach to the development of ideas in society, which I explore in the methodological interlude that follows this chapter, the relationship between the practices that 
embody the social imaginary and the prior theory or theories that have in some way informed this practice (before being rendered schematic through general social use) is a dialectical relationship (Taylor 2007, p. 177). This means that, like Archer, Taylor refuses to identify either structure (the social imaginary) or agency (social practice) as the final determining factor in social relations. Indeed, Archer argues that focusing on agency alone and offering a 'bottom-up' causal explanation would make 'no allowances for inherited structures, their resistance to change, the influence they exert on attitudes to change, and crucially. .., the delineation of agents capable of seeking change' (Archer 1995, p. 250). At the (posited) beginning of any particular history of a social imaginary there will be structural elements carried forward from preceding ways of being, reflecting previous expectations of acceptable practice.

This emphasizes that agents do not have completely free rein; again linking Archer and Taylor, it seems sensible to accept that any voluntary actions are going to be 'trammelled by past structural and cultural constraints and by the current politics of the possible' (Archer 1982, p. 470). Historically extant social imaginaries are themselves the products of previous clashes of social forces, previous interactions of ideas, material capabilities and institutions as I will elaborate in the methodological interlude. Agents' actions may be the immediate cause of specific moments of solidification, but they also remain embedded in larger structures, including material causes, state institutions and the structure of global capitalism that both constrain and empower as Taylor's own discussion of the wider context of social imaginaries indicates (Taylor 2004, 2007). However, as Archer also stresses, 'all structural influences ... are mediated to people by shaping the situation in which they find themselves' (Archer 1995, p. 196, emphasis in original). In a parallel analysis, towards what they term an interactional analysis of international law, Jutta Brunnée and Stephen Toope make a similar point:

[L]egal structures constrain social action, but they also enable action, and in turn are affected and potentially altered by the friction of social action against the parameters of the legal structure ... Stability may be aided by explicit articulation of a norm in a text, but it is ultimately dependent upon the underlying shared understanding and a continuous practice of legality. (Brunnée and Toope 2011, p. 112)

The key issue is therefore the difference between the inherited imaginary/ imaginaries (playing out in institutionalized practices) and the continuing (or changing) interests of specific agents. As I will set out when considering Archer's insights into agency and ideational change, where there is a mismatch between the structurally available benefits and the politicized 
interests of marginalized agents, this may be translated into tensions and strains in the system.

For now, the more important question is: is the rule of law a social imaginary? In Taylor's depiction, the social imaginary is all about a sense of the normal expectations and common understandings that enable the collective practices that make up our social life. The rule of law has at its centre an expectation about how rules and governance should proceed (or be practised) and indeed expectations as regards practice are central to the norm. Moreover, Taylor's suggestion that a social imaginary presents us with a sense of how we all fit together in carrying out this common practice again parallels the rule of law's establishment of the manner in which individuals can expect to work together constrained by specific laws. A social imaginary's provision of a repertory of practices is evident when it offers a limited range of actions that are acceptable, in that they demonstrate the law is being followed and its practices are to a large extent easily known. If a social imaginary is both factual and normative, providing both a sense of how things usually are and an idea of how they ought to be (what missteps would undermine such practice), the rule of law again would seem to be a social imaginary in its descriptive and normative treatments of what it is to be practising or working within the law, and what would be regarded as illegal (by virtue of the process of adjudication). In Taylor's argument a social imaginary involves a clear recognition of ideal cases from which judgements can then be made as regards the fit between imaginary and the practice; the rule of law structures exactly these sorts of judgements, not least of all in the debates about how such rule of law 'standards' might be operationalized.

In Taylor's treatment the imaginary is underdefined but nevertheless is a shared story of how we are, alongside a clear idea about how we might realize such a world. Certainly the rule of law as a norm is underdefined as the contested discussions around its meaning that I discuss later will demonstrate, but equally in its presentation of a set of consensual procedures seems able to offer a guide to how a minimal claim about the rule of law might be assembled. The development of the rule of law (as an idea) is itself dynamic and subject to the sorts of (social) forces of change that Taylor's account seems to encompass. Thus, Taylor's analysis allows an account to be developed both of how the rule of law as a social imaginary may have replaced other understandings of the mechanisms of global politics and why debates continue even if the basic idea of the rule of law seems to have become a global common sense.

Taylor's analysis of the social imaginary prompted Manfred Steger (2008) to examine the rise of the global imaginary and the practices by which this developed and has been contested. In one sense, what I will be 
doing in this book is developing one small aspect of the most recent global imaginary that Steger discusses as the 'morphology of market globalism' (Steger 2008, pp. 170-212). We might also understand the rise of the rule of law as a social imaginary to be (possibly) associated with the political development of the idea of a 'world community' typified by the rise of human rights as a mode of understanding a post-national human community of interest. For such a norm to develop it needs to be able to lay claim to the notion of a view above and beyond the plurality of human communities (Bartelson 2009, p. 181, passim) and as such if human rights remain contested in this regard it may be the case that the rule of law has been able to fill that role. In these two aspects of the global imaginary (the market and human rights) one other element of Taylor's description of the social imaginary comes into focus; the idea of the social imaginary as part of the background presumptions of the social is reflected by the rule of law being commonly seen (whatever the debates about its meaning and scope) as a key element of how we have chosen (as a human race) to govern ourselves. The rule of law is able to offer a globalized frame of reference for action inasmuch as it guides (relatively easily) the general travel of judgements about the politically acceptable and the unacceptable.

If the rule of law is a social imaginary, its normative appeal seems likely to be linked to its political value for communities and societies more widely than merely the members of any (global) political elite. This is likely because, as E.P. Thompson famously argued, the rule of law not only limits the actions of the ruled but constrains rulers as well: the law 'may disguise the true realities of power, but at the same time ... may curb that power and check its intrusions' (Thompson 1975, p. 265). Indeed, Thompson himself was keen to emphasize that due to the inhibitions it put upon power, the 'rule of law' was an 'unqualified human good' (Thompson 1975, p. 266), even while clearly identifying the injustice of particular laws. This reveals two assumptions that may be central to many casual appeals to the rule of law: firstly, that the most significant forms of power are (or can be) concentrated in government, which is then governed by, and governs through, the rule of law; secondly, that the rule of law itself can constrain and limit subjectively articulated power over individuals when such actions do not conform to the (objective) strictures of the law (Unger 1976, pp. 178-9). Of course, Thompson is aware that the law may not be able to fulfil all these hopes: there are forms of social power that are articulated outside the purview of the law and that it cannot constrain; the hoped-for objectivity can never be achieved because the rule of law must by definition be the rule of people through interpretation and adjudication - the police, lawyers and judges; and modern democratic states' governments as legislators can never be separate from the 
interaction of conflicting social interests. Nevertheless, Thompson's point is that whatever the compromises and shortcomings of the rule of law, it can deliver a better approximation of social justice than the absence of law is likely to achieve; Thompson's ends here are hardly (politically) eccentric or trivial (Krygier 2004, p. 257). However, Thompson adopts a relatively 'thin' (using a term that will be explained in Chapter 2) or procedural view of the law, requiring that all are treated equally under its rule. Certainly, unjust laws must be challenged, but the rule of law is better than its absence; it is a necessary but not sufficient condition for a just society in Thompson's view. ${ }^{1}$

As Karl Klare once pointed out (while offering qualified support for Thompson's position), '[t]o treat law as mere sham is to dishonour centuries of struggle in which the poor and oppressed attempted to fill the law with humane content, to hold the law to its own pretensions to justice' (Klare 1979, p. 133). While any analysis needs to engage with specific forms of law, it must also recognize the value of its more general normative and political claims, and Thompson was keen to emphasize that it is impossible to imagine a developed and complex market society without law (Thompson 1975, p. 260), and this of course is the power of its normative production in modern society. He goes on to argue there is an 'imbrication' (overlapping) of law and productive relations, which means that legal institutions and the capitalist market economy are always interconnected and impossible to completely separate. At the same time that laws structure productive relations (most obviously, but by no means exclusively, through property rights and legalized commodification), such law also changes in reaction to shifts in political economic relations mediated through the legal apparatus. In this analysis, the imbrication of law and productive relations is 'endorsed by norms' although such norms are always subject to conflict and need to be constantly (re)produced (Thompson 1975, p. 261). The structures of the law and the social relations of capitalist economic activity are not related in a unidirectional manner but rather are intertwined in a simultaneous layering, each one affecting the other. Relating this to the general appreciation of the social milieu, in the words of Phillip Corrigan and Derek Sayer, the law "works on and with wider moral classifications to "encourage" some ways of seeing (and being) and outlaw others ... [and] rules least noticeably yet most directly through its forms: through the ways in which it "encourages" us to present and represent ourselves' (Corrigan and Sayer 1981, pp. 40-1). It shapes and influences societies' practices at the same time that it reflects both

\footnotetext{
1 For an extensive discussion of Thompson's position on the rule of law, as well as a discussion of three important critiques, see Cole (2001).
} 
the deliberations over these practices and decisions on their individual applicability.

This approach to the rule of law, when worked through at the global level, has promoted analyses that identify a move to a form of global constitutionalism (which I discuss at some length in Chapter 6). Those who see this as a positive move regard the work of various international organizations (primarily, but not limited to, the World Trade Organization) as establishing a constitution for the global system, which while focused on certain issue areas is starting to establish a process by which a rule of law can develop its own character rather than being beholden to states and their (international) interests. For critics, this development is not so much the development of the rule of law as a governance mechanism parallel to that which has been developed in liberal states and which is subject to democratic deliberation, but is rather the imposition of a specific set of norms and rules that favour particular actors and foster a particular neoliberal structure to the global system. In this critique, the constitutionalization of the global system is actually neoliberalization; the rule of law on which such a shift is predicated is not a neutral technology but an extension and continuation of imperialistic domination by other means (Gill 2003; Mattei and Nader 2008). However, whatever one's view of global constitutionalism, the rule of law is not only required but has to have been established by some means; the rule of law does not support such developments 'naturally' and without its own political history.

Therefore, and responding to the arguments John Hobson has recently made about the endemic Eurocentrism of International Theory (Hobson 2012), I see the rule of law not only as a Western/European value to which non-Europeans respond/adapt but as a response itself to the manner in which global politics has developed during the last decades. There is a much longer legal and political history to which attention might be paid, but even in my shorter/narrower historical focus it is important to avoid obscuring the non-Western political pressures that have shaped and influenced the development of the rule of law in global politics. That is to say, we must not see an analysis of the rule of law merely being a product of US domination of the global system. Thus, the sort of approach offered by Anne-Marie Burley is partial and would need to be added to; at the beginning of the 1990s she argued that multilateralism is the

form to be expected from a set of international regimes established by a liberal state with a strong tradition of seeing the world in its own image and a missionary drive to make it so ... taking responsibility for the world meant regulating abroad as at home, in form as well as substance; more importantly, however, a mindset that could transfer the American administrative revolution to the world by formulating every problem in terms of a need for centralized intervention 
and every solution in terms of a regulatory institution was a mindset that itself was shaped by the liberal conception of the rule of law. (Burley 1993, p. 145)

While this still has some potential analytical purchase on the development of the rule of law as global common sense, here I want to suggest a more dialectical process behind the rule of law's conceptual hegemony. In a theme that will be returned to in a number of ways in the course of the argument, we might say (in the words of Rajeev Dhavan) that it is best to see law as struggle (Dhavan 1994): a struggle for meaning, a struggle for legitimacy and perhaps most obviously as a struggle to obtain and sustain justice. The parties to these struggles are varied and there are great inequalities of power but the norm of the rule of law is often both the subject of and the terrain over which these struggles take place. As E.P. Thompson once suggested: 'The greatest of all legal fictions is that the law itself evolves, from case to case, by its own impartial logic, true only to its own integrity, unswayed by expedient considerations' (Thompson 1975, p. 250). Rather, the rule of law can also be seen as the realm over which debates, deliberations and disputes over the appropriate balance of public and private power (in any given situation) may range (see, for instance, Friedmann 1971). The rule of law, although often presented as neutral, is deployed politically, but by both sides to different proposed ends.

As this suggests, one key aspect of this book is how we understand the 'normativity' of the law; how we understand the way law shapes and guides social actions by creating social obligations of one sort or another. Sylvie Delacroix has formulated the social position of law as follows:

[T] he normative dimension of the law cannot ever be taken as a 'given' established once and for all, provided the officials' minimal commitment condition is verified. Understood dynamically, law's normativity may be said to be brought about every day. Each time an individual is led to assess law's normative claims in the light of morality's demands, each time a judge is led to re-articulate what we want law for: these cases contribute to shaping the 'fabric' enabling law's normativity. (Delacroix 2009, p. 130)

Law's normative function is dynamic and constantly in a process of becoming through its interaction with the society that it is intended to govern. For Delacroix, the key to understanding normativity is appreciating any specific actors' commitment to the norm and how this is enacted, as well as the obligations it may entail. Systemic normativity is enacted through the actions and practices of those so 'guided'.

Moreover, this is not to be regarded merely as an instrumental relationship between norm and acting social individual (or corporate actor) but rather as the result of a dialectical relationship between the law (and its 
procedures) and common perceptions or prescriptions of the rule of law (Houtzager 2001, p. 11). Everyday socio-legal practices both (re)produce perceptions of the rule of law and also may shift the actual obligations this entails over time. Thus, in the international realm, as Brunnée and Toope suggest,

law is created, maintained or destroyed through day-to-day interactions of communities of legal practice. Legal obligation cannot be reduced to the existence of fixed rules; it is made real in the continuing practice of communities that reason with and communicate through norms. Although the stock of shared understandings may be relatively limited in international society, law making is possible ... To be meaningful, international law may need to track what little common ground there is, even if that ground is confined to a shared sense that future interactions should be legal, rather than purely social or political interactions. (Brunnée and Toope 2011, p. 131, emphasis in original)

This shared sense is, of course, the acceptance of the rule of law as a common sense, as a social imaginary, (re)produced through the practice of interactions between communities utilizing the rule of law as a common (background) norm.

Law's normativity, however, is understood quite differently by economists and legal analysts; the former see the law as a set of incentives that are intended in some manner to support the (re-)emergence of equilibrium in social relations, while the latter see normativity as part of a structure of socialized obligation and (often) reciprocal agreement that the rule of law delivers social value (Kornhauser 1999). Rather than seeking to choose between these two understandings, I work on the basis that they are complementary aspects of the rule of law, which while potentially balanced differently in any specific case are both always present when seeking to fully appreciate how the rule of law works as a normative force in social relations. Another way of expressing this is to follow Robert Cover and stress that

law is neither to be wholly identified with the understanding of the present state of affairs nor with the imagined alternatives. It $i s$ the bridge - committed social behaviour which constitutes the way a group of people will attempt to get from here to there. (Cover 1995, p. 176, emphasis in the original)

The rule of law, then, is how societies are shaped by their views about the good life as refracted through governing practice(s), partly a statement of social obligation, partly a structure of incentives (albeit mostly negative). When there are conflicts between reasons for acting (or not acting) the legal is the final arbiter of a decision (even if in any particular consideration this is not made explicit). The 'political' problem of the rule of law 
is that either consciously or inadvertently across (global) politics, actors have a tendency to elevate their political values to those of more neutral (but potentially enforceable) legal norms that are then intended to 'trump' other reasons for other actions and practices (Spaak 2005, p. 400). Thus, as the rule of law norm has 'emerged' as a key element of global politics, so it has acted to (partly) depoliticize conduct and conflicts.

\section{THE SOCIAL IMAGINARY OF THE RULE OF LAW AND GLOBAL POLITICS}

Let's pause a minute and test whether the rule of law is part of your common sense (a social imaginary you recognize); try for a minute to think whether you would like to live in a world that was not governed by law(s). As Paul Kahn puts it, this is almost the 'equivalent of imagining a world without gravity' (Kahn 1999, p. 4). Although, to be fair, if you are a (political) anarchist, then you will likely believe a world without laws is possible, ${ }^{2}$ but for everyone else I contend that even if you are unfamiliar with the details of the legal system, you are likely in general terms to favour the rule of law. We might then ask whether the expansion of the rhetoric of the rule of law indicates the strength of the norm or that the rule of law is subject to increasing challenge. If the latter, the articulation of the common sense is inversely proportional to its acceptance; the rule of law is not celebrated because it has finally been established but because it is often challenged, or does not command uncritical allegiance.

Therefore, one of the chief reasons for writing this book is a belated response to David Kennedy's observations (made over a decade ago) that:

Those most enthusiastic about the rule of law as a development strategy treat it as a recipe or ready-made rather as a terrain for contestation and strategy ... From a lawyer's point of view, these ideas about law expect the legal order to perform feats we know it rarely can accomplish and expect law to remain neutral in ways we know it cannot. (Kennedy 2004, p. 157)

Indeed, as he goes on to argue, depoliticization is rife:

The idea that building the 'rule of law' might itself be a development strategy encourages the hope that choosing law in general could substitute for all the perplexing political and economic choices which have been at the centre of development policy making for half a century ... The campaign to promote the

2 But also see Taiwo (1999) for an argument for why some Marxists might also disagree with Thompson's (quasi) Marxist appeal to the rule of law. 
rule of law as a development path has encouraged policy makers to forgo pragmatic analysis of the choices they make in building a legal regime - or to think that the choices embedded in the particular regime they graft onto a developing society represent the only possible alternative. (Kennedy 2004, p. 151, emphasis in original)

The rule of law is not as simple as the discourse popularly promulgated would imply, even though much expert commentary has come to accept (and set out) these complications and variability. Kennedy's remarks have a wider salience than merely the realm of development and legal capacity building or technical assistance (although this is an important area that I will examine later), but rather indicate something about the utilization of the idea of the rule of law more widely.

The rule of law has become a common sense discourse (a social imaginary) meant to both describe the global system but also act as a guide for what ought to be happening. It has joined human rights and democracy to become part of what Amachai Magen has called the 'virtuous trilogy' upon which legitimate international order is now regarded as resting (Magen 2009, p. 53). As David Sugarman and Ronnie Warrington have pointed out:

Law is an influential story: it is one of the privileged ways through which society presents and defines the world to itself ... Law is more than a structure of restraint, setting the boundaries within which individuals pursue their self interest. It is one of the major processes by which the dominant representations of society are created and justified. Law, is therefore, one of the major languages through which ideas are expressed. (Sugarman and Warrington 1995, p. 126)

Thus, when the rule of law is invoked it suggests that what is at stake is not merely the existence of law, but something more; we seem to be invited to evaluate the legitimacy of a system of laws in a specific circumstance. That is to say, the rule of law is about more than the laws themselves; it is concerned with the (social) values that are expressed through those laws, and whether these values are legitimately furthered or promoted through a legal system (Humphreys 2010, p. 5). Evaluations of the rule of law have become central to the manner in which judgements are made about which states, or political groups and organizations, are friends and which are enemies. Those identified as following or working through the rule of law are to be regarded as acting acceptably, and those identified as falling short are regarded as problematic societies, failed states or enemies (Adler and Bernstein 2005, pp. 309-10). The rule of law is not merely a value that is applied to domestic states, but is also presented as an aspiration for the international realm. Indeed, the articulation of the (global) social imaginary of the rule of law is clearly evident at the United Nations (UN). 
At the end of the Cold War (and in response to the general presumption that this was a historical threshold) the UN launched the Decade of International Law (1990-99) (UN Resolution 44/23, 17 November 1989). ${ }^{3}$ Unlike other UN 'decades', for women or biodiversity, this decade was rather low key with little associated publicity and as such it is difficult to establish a direct causal link between this UN decade, states' actions and the expansion of the rhetoric (Suter 2004, p. 352). A year after the end of the decade, the UN's Millennium Declaration stressed the need to strengthen the rule of law three times; firstly, under Peace, Security and Disarmament, the declaration noted a need 'To strengthen respect for the rule of law in international as in national affairs and, in particular, to ensure compliance by Member States with the decisions of the International Court of Justice, in compliance with the Charter of the United Nations, in cases to which they are parties.' Secondly, under Human Rights, Democracy and Good Governance, the text declared, the UN 'will spare no effort to promote democracy and strengthen the rule of law, as well as respect for all internationally recognized human rights and fundamental freedoms, including the right to development'. Finally, under Strengthening the UN, the document suggests a need to 'strengthen the International Court of Justice, in order to ensure justice and the rule of law in international affairs'. ${ }^{4}$ That said, while recognized as an enabling mechanism, the subsequent Millennium Development Goals (MDGs) did not explicitly include a rule of law-related goal. ${ }^{5}$ If this was due to those focused on the rule of law failing to make the case for their inclusion, subsequently the rule of law has continued rising up the political agenda, which suggests that in the post-2015 reconfiguration of the UN's strategic developmental goals, the rule of law will likely be much more central.

Indeed, since the 2005 UN World Summit (celebrating 60 years of the $\mathrm{UN}$ ) when the rule of law was identified as one of the four key areas that demanded greater attention by the $\mathrm{UN}$ and its associated organizations, supporting the rule of law (most often in post-conflict societies) has become a major element in the work of the UN (Bull 2008, p. 5, passim). More recently, on 24 September 2012 the UN General Assembly held a 'highlevel meeting' on the rule of law, bringing heads of state and governments

${ }^{3}$ The text of the resolution is available at http://www.un.org/documents/ga/res/44/a44r023. htm (accessed 8 May 2013).

4 All quotes from the Millennium Declaration at http://www.un.org/millennium/declara tion/ares552e.htm (accessed 9 May 2013).

${ }^{5}$ The MDGs are: Eradicate Extreme Hunger and Poverty; Achieve Universal Primary Education; Promote Gender Equality and Empower Women; Reduce Child Mortality; Improve Maternal Health; Combat HIV/AIDS, Malaria and Other Diseases; Ensure Environmental Sustainability; Develop a Global Partnership for Development. 
together with the General Assembly to 'reaffirm our commitment to the rule of law and its fundamental importance for political dialogue and cooperation among all states' (UNGA 2012, p. 1). The resulting document goes on to assert the link between the rule of law and human rights, development, an independent judiciary, and equal access to justice as well as a number of other elements usually regarded as being central to an evaluation that the rule of law obtains in any specific instance. By linking the national and international rule of law the document reflects a shift in the focus of the 'international community'; the UN Decade of International Law was focused on the rule of law between states, but this has been developed (through the processes that this book focuses on) to produce a linked political concern with the rule of law within states (Bouloukos and Dakin 2001, p. 147; Pahija 2011, pp. 172-253). The ascendance to the role of (global) societal value spans domestic and international/global concerns about governance.

Reflecting this support for the rule of law the UN website now has a dedicated section (under international law) on the United Nations and the Rule of Law, which starts with the following paragraph:

Promoting the rule of law at the national and international levels is at the heart of the United Nations' mission. Establishing respect for the rule of law is fundamental to achieving a durable peace in the aftermath of conflict, to the effective protection of human rights, and to sustained economic progress and development. The principle that everyone - from the individual right up to the State itself - is accountable to laws that are publicly promulgated, equally enforced and independently adjudicated, is a fundamental concept which drives much of the United Nations work. ${ }^{6}$

The page then goes on to briefly expand on how the rule of law is 'embedded' in the UN's activities, noting that '[o]ver $40 \mathrm{UN}$ entities are engaged in rule of law issues and the Organization is conducting rule of law operations and programming in over 110 countries in all regions of the globe'. The page offers links to key documents and statements, but in the top right hand corner also has a large box that links to the dedicated UN Rule of Law website and documentary repository. ${ }^{7}$ The dedicated website offers a wealth of materials, documents and reports on UN activities related to the rule of law as well as more thematic policy documents and other resources including training and practitioner networks. The range of resources on offer demonstrates that the rule of law is a major element in the discourse of governance that is mobilized by the UN through its work

\footnotetext{
${ }^{6}$ http://www.un.org/en/ruleoflaw/index.shtml (accessed 1 May 2013).

7 http://www.unrol.org/ (accessed 1 May 2013).
} 
and complements the extensive material available on the World Bank's website. However, the structures of the UN and its charter, as well as the particular character of the international realm, have meant that (as I will discuss later) the UN Security Council (UNSC) is both (potential) champion of the rule of law but (problematically) hardly constrained by rule of law considerations in the final instance. ${ }^{8}$

Sometimes the norm of the rule of law can act to obscure differences between (national) versions of legal practice and can present them as part of the established, legitimate and achieved (global) political settlement. Jurisprudential discussions of the rule of law are consequently often of less importance to the norm than a purely legal analysis might assume. In this sense, I am interested in the norm of the rule of law in a similar manner to which Jason Sharman is interested in the manner in which the rhetoric around tax havens operates to establish various regulatory norms (Sharman 2006). One of the key parallels between our projects is that like the term 'tax haven', the rule of law is a site of contest(s) about meaning. However, the negative evaluation encapsulated by the term tax haven has significant impact on states' reputation as regards their ability to secure inflows of foreign investment. Conversely, the term rule of law is a badge of modernity, political legitimacy and acceptable political behaviour. To some extent my perspective here is a mirror image of Sharman's given that I am interested in the normative and positive reputational impact of claims to be governed by the rule of law.

In Sharman's study of the campaign by the OECD against (so-called) tax havens, he argues that the use of rhetoric and the political norms so 'performed' can lead to certain political actions becoming difficult if not impossible. This parallels my concerns as it is this notion of rhetorical power as deployed when the rule of law is raised in political debate that I am interested in. Sharman concludes that:

The potential for the powerful to be entrapped by the stratagems of the weak, the slipperiness of meaning and language, and the unpredictability of policy effects mean that the control of dominant actors is never unchallengeable and their projects rarely go to plan. But international political economy is still most commonly a matter of the strong regulating as they will and the weak suffering as they must. The interplay of rhetoric and reputation may just as readily entrench inequalities as undermine them. (Sharman 2006, p. 161)

In Sharman's study the 'weak' were able to mobilize the OECD's norms to defend themselves against some political interventions (over

\footnotetext{
8 See Chesterman (2008a) for an interesting set of recommendations intended to allow the UNSC to more fully shackle itself to rule of law norms and standards of practice.
} 
non-intervention/sovereignty and the OECD's role as adjudicator not legislator, for instance); in the analysis of the rule of law I develop herein, what is most important in understanding the rhetoric is the widespread use of the normative claim, even though it is often 'honoured in the breach'. Understanding the rule of law and its rhetoric nevertheless taps into the same issues Sharman examines: the role of reputation as a relational quality and the role of rhetoric (rather than necessary action) in the attempt to maintain a reputation in the global political economy. This is especially relevant to the OECD as at the fourth World Justice Forum (in 2013) their head of statistics and indicators announced that the OECD now would be using the World Justice Project's Rule of Law index, which I discuss briefly later, as its authoritative indicator. ${ }^{9}$

There is also a considerable amount of commentary on the rule of law (to which I will return) that suggests that the rule of law is a form of conveyor belt for liberalization; that introducing the rule of law into the economic sphere will foster a form of spill-over into other areas of society and thereby act as a prompt to liberalization, although, as often this link seems to be more a matter of faith than hard evidence (Silverstein 2003), it again stresses that the rule of law is a social imaginary. Brian Tamanaha has described this position as:

A mutually reinforcing circle exists, according to this faith, in which the rule of law begats democracy, which begats social welfare capitalism, which begats liberal rights, which begats women's rights. The causal arrows presumably go in all directions, each supporting the other, with the rule of law bearing substantial weight and responsibility for the whole. (Tamanaha 2011, p. 233)

He goes on to suggest that the difficulty is that while the rule of law is often treated by its (developmental) proponents as a general purpose technology, actually it is part of a mutually supporting set of institutions and practices that do not necessarily obtain whenever the rule of law is introduced as a political solution (Tamanaha 2011, pp. 235, 237). The actors that seek to deploy the law-as-technology are an important part of the analysis I develop later, not least of all as one of the key changes that seems to me to lie behind the expansion of the rhetoric of the rule of law (and its celebration) is the increasing professionalization of much of global politics, which has normalized the notion of the rule of law into a fundamental value of global politics; the common sense of global politics or its social imaginary.

9 Zsuzsanna Lonti, presentation, World Justice Forum IV, Den Haag, Netherlands, 9 July 2013. 
I have now set out the main themes that I will be exploring in this book, and in the following methodological interlude I will say something about how I will approach these themes; that is to say, I will discuss how I do political economy. Once I have introduced my method, I then set out the range of ideas about legality that have patterned the jurisprudential discussion of the rule of law, before then (in Chapter 3) seeking to identify the agents through whom the (re)production of the rule of law as a common sense (the process of legalization) takes place. In the following two chapters (4 and 5) I examine how this plays out on the ground in two areas that have been the focus for much activity and commentary related to the rule of law: firstly, in post-conflict states where programmes seek to build (legal) capacities to reintroduce social order; then following a discussion of the rule of law as a developmental 'technology' I explore in a more general sense the link between the rule of law and the capitalist system of economics (and its links to economic development). I then refocus (in Chapter 6) on the idea of a global constitution (based, as it must be, on the rule of law), before in the last main chapter exploring two modes of challenge to the rule of law, one internal - civil disobedience - and one external or structural - the extent of legal pluralism - which in some senses undermines claims for a universalized rule of law in any substantive sense. The book concludes with some final reflections on the rule of law. 